\title{
STATITIONARY ENGINE PERFORMANCE USING MIXTURE OF SOYBEAN AND CASTOR BEAN BIODIESEL TO DIESEL OIL
}

\author{
Jorge W. Cortez ${ }^{*}$, Camila C. Guimarães ${ }^{2}$, Vivianni M. L. dos Santos ${ }^{3}$ \\ ${ }^{1 *}$ Corresponding author. Universidade Federal da Grande/ Dourados - MS, Brasil. E-mail: jorgecortez@ufgd.edu.br
}

\section{KEYWORDS}

Agroenergy, diesel

engine,

biodiesel/diesel

mixtures, oleaginous, engine rotation.

\begin{abstract}
The use of alternative fuels in diesel engines has been the subject of research that seeks new fuels to expand the energy matrix. The aim of this study was to evaluate the performance of the stationary engine with the use of mixtures of biodiesel from soybean and castor bean added to diesel (S500) in two proportions (25\% and $40 \%)$, evaluating the torque, effective power observed and specific consumption. The five biodiesel mixtures of soybean (S) and castor bean (C) analyzed were: S100C0, S75C25, S50C50, S25C75 and S0C100, which were added to the diesel in proportions B25 and B40, totaling ten treatments, plus the control with diesel S500 (B7). The stationary engine was subjected to the rotations of $3000,2700,2400,2100,1800$ and $1500 \mathrm{rpm}$. The performance of the engine was similar for all biodiesel mixtures of soybean and castor bean, and commercial diesel (B7). The B40 S100C0 and B40 S75C25 provide better performance in terms of effective power observed and torque at $2700 \mathrm{rpm}$. The highest effective maximum power (3000 rpm) was obtained with the use of B7 diesel. In the lower rotations, it was possible to identify a similar performance result of the biodiesel mixtures with the B7, in addition to providing better torque and consumption performance compared to the commercial diesel.
\end{abstract}

\section{INTRODUCTION}

Most machines, currently used in agriculture, for mobility or power generation, are equipped with diesel cycle engines because of the efficiency they present. However, the unavailability prediction of long-term of fossil fuels and the emission of pollutants has stimulated research on biofuels (Perin et al., 2015), mainly with respect to environmental, economic, political, cultural and technical aspects for agriculture (Ballesteros et al., 2014).

Among the biofuels, the biodiesel is an attractive option for use in diesel engines, and can be produced from oil sources, with the characteristic of being biodegradable, renewable, non-toxic (Selvam \& Vadivel, 2013), presenting high energy density, compatibility with existing engines, low NOx and SOx emissions after combustion (Rashid et al., 2014) and less impact on $\mathrm{CO}_{2}$ emissions in relation to fossil derivatives (Chauhan et al., 2013; Zhou et al., 2014).

The biodiesel has been used in diesel cycle engine in combination with diesel, with soybean being the main source used for its production, a factor that has stimulated the investigation of the effects of the use of biodiesel from other sources and percentages. Castellanelli et al. (2008), for example, found that torque, power and specific consumption were similar between B0 (diesel), B2, B5 and $\mathrm{B} 10$, and the best engine performance occurred with B20 and the worst with soybean B100. Nietiedt et al. (2011) identified better potency and consumption with the use of B10 and the worse with B100 compared to B5 and B20.

The biodiesel from soybean is one of the most susceptible to oxidation, unlike castor bean biodiesel that presents greater stability and, in mixture with the soybean, promotes an increase in the resistance time to oxidative factors (Carvalho et al., 2013). However, particular physical-chemical characteristics of castor bean biodiesel, such as high viscosity, make difficult to use this biodiesel, and necessary to investigate the effects of this fuel on the performance of internal combustion engines (Monteiro et al., 2013).

Faced the need to reduce the dependence on the use of raw material, currently concentrated in soybeans, and to promote adequate insertion of oleaginous sources that present restrictions on the mechanical performance of the engine, as it is the case of castor bean biodiesel. The aim of this study was to evaluate the performance of the

\footnotetext{
${ }^{2}$ Universidade Federal do Oeste da Bahia/ Bom Jesus da Lapa - BA, Brasil.

${ }^{3}$ Universidade Federal do Vale do São Francisco/ Juazeiro -BA, Brasil.

Received in: 4-17-2018

Accepted in: 9-17-2018
} 
stationary engine with the use of mixtures of biodiesel from soybean and castor bean oil added to diesel (S500) in two proportions $(25 \%$ and $40 \%)$, evaluating the torque, effective power observed and specific consumption.

\section{MATERIAL AND METHODS}

The study was conducted in a laboratory at the Federal University of the São Francisco Valley (UNIVASF), in Juazeiro (BA), located at an altitude of $368 \mathrm{~m}$, which temperature of the test site was on average $27^{\circ} \mathrm{C}$, in a controlled condition.

The biodiesel from soybean, obtained by methanol transesterification with alkaline catalysis, used to evaluate the performance of the engine in terms of effective power observed, specific consumption and torque, was provided by Granol (GO), while the castor biodiesel was transesterified with the support of the Experimental Biodiesel Plant of Caetés (PE).
The experiment was set up in a completely randomized design, with six replicates, with one control. The five mixtures analyzed resulted from combinations of biodiesel from soybean and castor bean, being designated by the symbol "SyCx", where "S" corresponds to soybean biodiesel and " $\mathrm{C}$ " to castor biodiesel, whose concentrations (\%) are equivalent to " $\mathrm{y}$ " and " $\mathrm{x}$ " respectively. Thus, the mixtures S100C0, S75C25, S50C50, S25C75 and S0C100 were added to the commercial diesel S500 (currently with $7 \%$ biodiesel, B7) to obtain proportions with 25\% (B25) and $40 \%$ biodiesel (B40), totaling ten treatments, plus the control (B7).

The $\mathrm{BX} / \mathrm{SyCx}$ mixtures were subjected to 3000 , $2700,2400,2100,1800$ and $1500 \mathrm{rpm}$ rotations for stationary engine analysis. The quality control parameters of the fuels used are shown in Table 1, as well as the limits established by the National Petroleum Agency, Natural Gas and Biofuels according to ANP Resolution $n^{\circ} 45$ (2014).

TABLE 1. Specification of the fuel quality in terms of kinematic viscosity, oxidation stability and specific mass.

\begin{tabular}{|c|c|c|c|c|c|c|}
\hline \multirow[t]{2}{*}{$\begin{array}{c}\text { Mixtures } \\
(\mathrm{SyCx})\end{array}$} & \multicolumn{2}{|c|}{$\begin{array}{c}\text { Kinematic viscosity at } \\
40^{\circ} \mathrm{C} \\
{\left[3-6 \mathrm{~mm}^{2} \mathrm{~s}^{-1}\right]} \\
\left(\mathrm{mm}^{2} \mathrm{~s}^{-1}\right)\end{array}$} & \multicolumn{2}{|c|}{$\begin{array}{l}\text { Stability to oxidation } \\
{[6 \mathrm{~h}]} \\
\text { (h) }\end{array}$} & \multicolumn{2}{|c|}{$\begin{array}{c}\text { Specific mass } \\
\text { at } 20^{\circ} \mathrm{C} \\
{\left[850-900 \mathrm{~kg} \mathrm{~m}^{-3}\right]} \\
\left(\mathrm{kg} \mathrm{m}^{-3}\right)\end{array}$} \\
\hline & $\mathrm{B} 25$ & B40 & $\mathrm{B} 25$ & B40 & B25 & B40 \\
\hline $\mathrm{S} 100 \mathrm{C} 0$ & 3.19 & 3.35 & 10.6 & 8.0 & 843 & 858 \\
\hline $\mathrm{S} 75 \mathrm{C} 25$ & 3.31 & 3.70 & 7.6 & 6.5 & 853 & 863 \\
\hline S50C50 & 3.38 & 4.17 & 11.0 & 10.9 & 853 & 869 \\
\hline $\mathrm{S} 25 \mathrm{C} 75$ & 3.49 & 4.66 & 19.2 & 17.3 & 860 & 871 \\
\hline S0C100 & 3.84 & 5.26 & 31.0 & 25.0 & 857 & 873 \\
\hline B7 & \multicolumn{2}{|c|}{3.03} & \multicolumn{2}{|c|}{35.0} & \multicolumn{2}{|c|}{838} \\
\hline
\end{tabular}

For the tests of the engine performance, in terms of effective power observed, specific consumption and torque, an electric dynamometer was used, consisting of a three-phase Negrini generator, with $36 \mathrm{kVA}$ of power, $1800 \mathrm{rpm}$ and 220 volts and a three-phase resistive bench, in which a stationary diesel engine was tested, BD 10.0 model of the Branco brand, mono-cylindrical, 4-stroke, direct injection of fuel and nominal power of $5.7 \mathrm{~kW}$ at $3000 \mathrm{rpm}$ and $6.7 \mathrm{~kW}$ at $3600 \mathrm{rpm}$.

Triggered by the machine in test (engine), the generator produced electric energy that was consumed by $8.64 \mathrm{~kW}$ three-phase resistive bench, connected to the output of the generator, which allowed to determine the power through the generated voltage and current.

The test procedure consisted of inserting the $\mathrm{BX} / \mathrm{SyCx}$ mixtures into the engine fuel tank, which remained initially for 5 minutes at low speed for heating and lubricating of the engine. After the heating, the engine was subjected to maximum rotation of $3600 \mathrm{rpm}$, condition in which it remained for 30 minutes. Then, the resistive bench was connected and after 15 minutes of stabilization the rotation (stabilized at $3000 \mathrm{rpm}$ ) was measured with a digital tachometer ICEL TC 5030 (accuracy: $\pm 0.05+1 \mathrm{D}$ ); the voltage, with digital Minipa Meter ET-2907 (precision: $\pm(0.3 \%+10 \mathrm{D})$; and the generated current, with Minipa ET-3200A ammeter (accuracy: $\pm(2.0 \%+5 \mathrm{D})$.

The volumetric consumption of the mixtures was obtained with a volumetric meter, constituted by a graduated burette, coupled to the power line of the motor through a hose, according to Reis et al. (2013). The fuel consumption time was measured with the KENKO KK 2808 digital timer.

After the measurements, the rotation was reduced to $2700 \mathrm{rpm}$, repeating the procedure described above for the measurement of rotation, voltage, current and consumption, and so on for rotations of 2400, 2100, 1800 and $1500 \mathrm{rpm}$. The test was repeated six times for each mixture, removing all tested fuel contained in the engine reservoir at the end of each test.

Based on the current and voltage data, the effective power observed produced by the engine was determined under the atmospheric conditions (Equation 1), according to Kosow (1982).

$$
E P_{\text {observed }}=\sqrt{3} * V * I
$$

That,

$$
\begin{aligned}
& \text { EP (observed) - Power (Watts); } \\
& \text { V- Voltage output, and } \\
& \text { I - Output current (Ampere). }
\end{aligned}
$$

It is worth noting that according to the engine manufacturer's catalog, for the ambient conditions above $305 \mathrm{~m}$ altitude, it has a loss of $3.5 \%$ in power and every $5.6^{\circ} \mathrm{C}$ above the standard temperature $\left(15.6^{\circ} \mathrm{C}\right)$, it loses $1 \%$ of power.

The specific fuel consumption was determined according to Mialhe (1996), from the values of mass of fuel consumed, measured power and time (Equation 2). 


$$
\mathrm{SFC}=\frac{3.6 * 10^{3 *} \mathrm{C}^{*} \mu}{\mathrm{EP} \text { observed }}
$$

that,

$S F C$ - Specific fuel consumption $\left(\mathrm{g} \mathrm{kW}^{-1} \mathrm{~h}^{-1}\right)$;

$C$ - Hourly consumption $\left(\mathrm{mL} \mathrm{s}^{-1}\right)$, and

$\mu$ - Specific mass $\left(\mathrm{kg} \mathrm{m}^{-3}\right)$.

With the values of effective power observed and rotation, the torque (Equation 3) was obtained, according to Mialhe (1980).

$$
T=\frac{E P_{\text {observed }} * 974}{r p m}
$$

that,

$$
\begin{aligned}
& T \text { - Torque (kgf m), and } \\
& r p m \text { - Engine speed (rotations per minute). }
\end{aligned}
$$

The data were submitted to analysis of variance and Tukey's test was applied at 5\% probability. In addition, regression analysis was carried out to describe the behavior of torque, effective power observed and specific consumption as a function of the rotations.

\section{RESULTS AND DISCUSSION}

Significant differences were observed in the results of effective power observed, specific consumption and torque from the $\mathrm{BX} / \mathrm{SyCx}$ mixtures and the operating

A

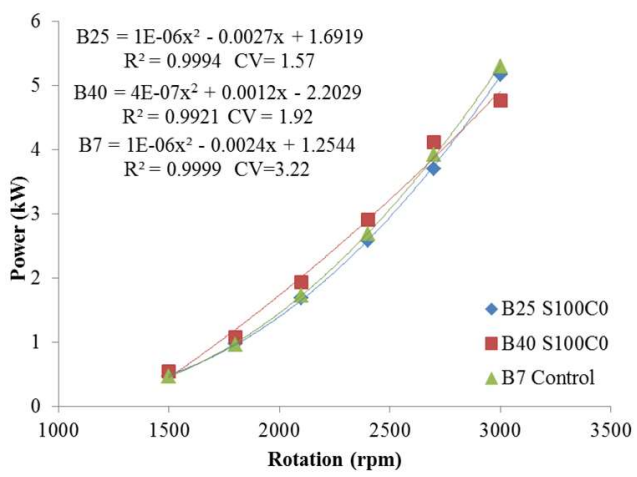

$\mathrm{C}$

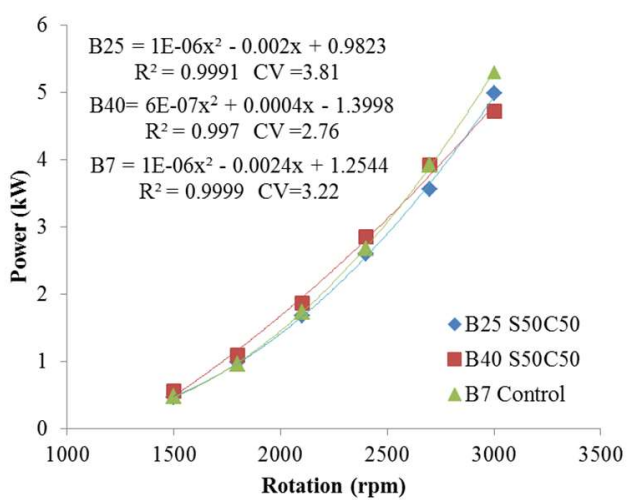

regimes (rotations), as well as for the interaction of these factors with each other.

The performance of the engine, from the effective power observed, in relation to the rotations used (Figure 1 ), indicates an increase in power using the proportions B25 and B40, according to soybean and castor bean biodiesel mixtures ( $\mathrm{SyCx})$, similar to that obtained with B7. In general, the effective power observed increases as the rotation increases, reaching maximum value at the maximum rotation imposed, corresponding to $3000 \mathrm{rpm}$, regardless of the proportion of biodiesel (BX) or mixture (SyCx) analyzed.

The increase in the castor bean biodiesel concentration in the mixtures promoted reduction of the maximum potency using the proportions B25 and B40 compared to B7 (Figure 1), so that these points are further from the commercial diesel (B7) when using the mixtures S25C75 (Figure 1D) and S0C100 (Figure 1E), with power of 4.48 and $4.36 \mathrm{~kW}$ respectively, while the diesel presented $5.30 \mathrm{~kW}$ of power (Table 2). The distance from the curves, from certain ranges of rotation, was justified by Castellanelli et al. (2008) as a phenomenon associated with inefficient fuel atomization due to the higher viscosity of biodiesel.

In this case, although all mixtures of biodiesel from soybeans and castor bean and proportions of diesel/biodiesel studied presented viscosity and oxidative stability (Table 1) within the limits established by the ANP, the increase of castor bean biodiesel concentration in the mixture increases considerably the viscosity.

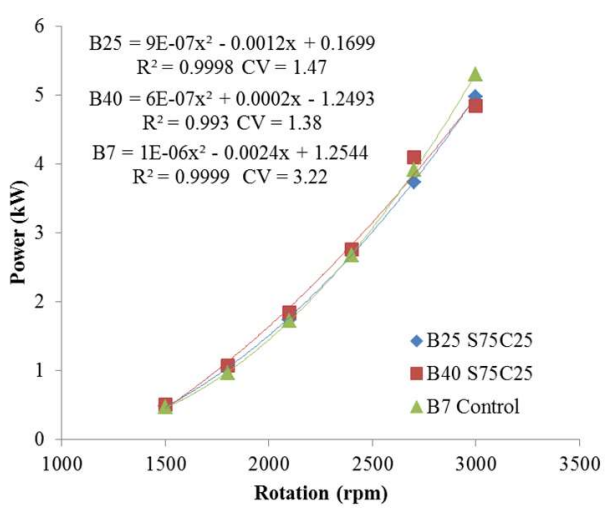

$\mathrm{D}$

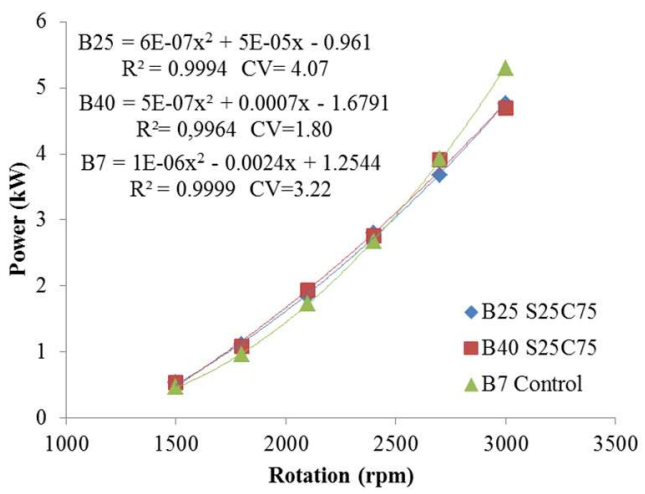


$\mathrm{E}$

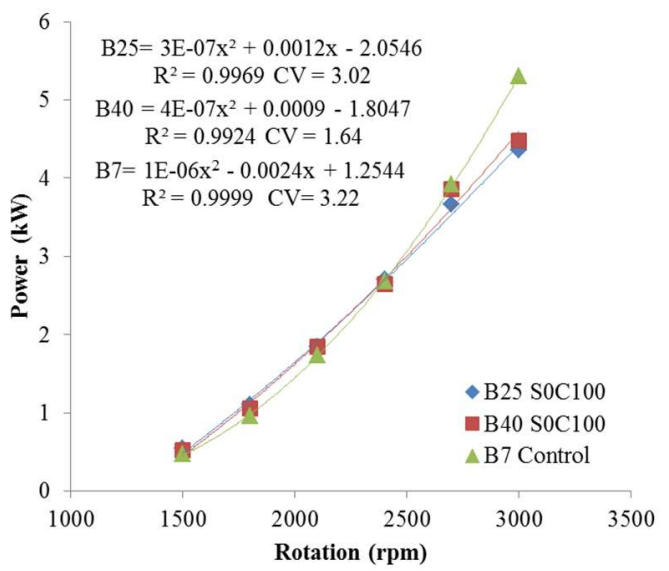

FIGURE 1. Effective power curves observed as a function of engine rotation, using the proportions B25 and B40 with the mixtures: (A) S100C0; (B) S75C25; (C) S50C50; (D) S25C75 and (E) S0C100 compared to the diesel B7 control.

For the maximum rotation $(3000 \mathrm{rpm})$, the engine had the highest effective power observed with the use of B7 (diesel), followed by the use of B25 with $100 \%$ of soybean biodiesel (S100C0), which presented a 2.5\% reduction compared to diesel (Table 2). There were reductions in the maximum power values, with the use of higher proportions of biodiesel added to commercial diesel, which, according to Nietiedt et al. (2011), may be related to the lower calorific value of the biodiesel. The reduction of the energy power is related to the presence of oxygen in the fuel molecule, which is a characteristic of the biodiesel (Iscan \& Aydin, 2012), which varies according to the raw material used in its production (Boldaji et al., 2011).

TABLE 2. Average of the effective power observed for the BX/SyCx mixtures as a function of the rotation, the overall average of the effective power observed as a function of biodiesel types/proportions and variance analysis synthesis.

\begin{tabular}{llllllll}
\hline \multicolumn{7}{c}{ Effective power observed $(\mathrm{kW})$} & \multirow{2}{*}{ Overall average } \\
\cline { 2 - 6 } BX/SyCx Mixtures & 3000 & 2700 & 2400 & 2100 & 1800 & 1500 & $2.42 \mathrm{de}$ \\
\hline B25 S100C0 & $5.17 \mathrm{~b}$ & $3.70 \mathrm{de}$ & $2.58 \mathrm{f}$ & $1.68 \mathrm{c}$ & $0.97 \mathrm{bc}$ & $0.47 \mathrm{a}$ & $2.55 \mathrm{a}$ \\
B40 S100C0 & $4.77 \mathrm{de}$ & $4.12 \mathrm{a}$ & $2.90 \mathrm{a}$ & $1.93 \mathrm{a}$ & $1.07 \mathrm{abc}$ & $0.54 \mathrm{a}$ & $2.45 \mathrm{~cd}$ \\
B25 S75C25 & $4.98 \mathrm{c}$ & $3.74 \mathrm{~cd}$ & $2.72 \mathrm{~cd}$ & $1.74 \mathrm{bc}$ & $1.04 \mathrm{abc}$ & $0.48 \mathrm{a}$ & $2.52 \mathrm{ab}$ \\
B40 S75C25 & $4.84 \mathrm{~d}$ & $4.10 \mathrm{a}$ & $2.76 \mathrm{bcd}$ & $1.85 \mathrm{ab}$ & $1.07 \mathrm{abc}$ & $0.51 \mathrm{a}$ & $2.37 \mathrm{f}$ \\
B25 S50C50 & $4.98 \mathrm{c}$ & $3.55 \mathrm{e}$ & $2.59 \mathrm{ef}$ & $1.68 \mathrm{c}$ & $0.98 \mathrm{bc}$ & $0.46 \mathrm{a}$ & $2.50 \mathrm{bc}$ \\
B40 S50C50 & $4.72 \mathrm{de}$ & $3.91 \mathrm{~b}$ & $2.85 \mathrm{ab}$ & $1.86 \mathrm{a}$ & $1.09 \mathrm{ab}$ & $0.55 \mathrm{a}$ & $2.45 \mathrm{~cd}$ \\
B25 S25C75 & $4.76 \mathrm{de}$ & $3.68 \mathrm{~d}$ & $2.80 \mathrm{abc}$ & $1.84 \mathrm{ab}$ & $1.11 \mathrm{a}$ & $0.53 \mathrm{a}$ & $2.49 \mathrm{bc}$ \\
B40 S25C75 & $4.69 \mathrm{e}$ & $3.91 \mathrm{~b}$ & $2.76 \mathrm{bcd}$ & $1.93 \mathrm{a}$ & $1.08 \mathrm{abc}$ & $0.54 \mathrm{a}$ & $2.37 \mathrm{f}$ \\
B25 S0C100 & $4.36 \mathrm{f}$ & $3.66 \mathrm{de}$ & $2.71 \mathrm{cde}$ & $1.84 \mathrm{ab}$ & $1.10 \mathrm{a}$ & $0.54 \mathrm{a}$ & $2.40 \mathrm{ef}$ \\
B40 S0C100 & $4.48 \mathrm{f}$ & $3.86 \mathrm{bc}$ & $2.65 \mathrm{def}$ & $1.84 \mathrm{ab}$ & $1.05 \mathrm{abc}$ & $0.52 \mathrm{a}$ & $2.51 \mathrm{ab}$ \\
B7 & $5.30 \mathrm{a}$ & $3.92 \mathrm{~b}$ & $2.68 \mathrm{def}$ & $1.73 \mathrm{bc}$ & $0.96 \mathrm{c}$ & $0.47 \mathrm{a}$ & 2.59 \\
\hline
\end{tabular}

Averages followed by same letter in column do not differ by Tukey test $(\mathrm{p}<0,05)$. CV: coefficient of variation $(\%)$.

In the rotations between 2700 and $1500 \mathrm{rpm}$ (Table 2), with the proportions B40, the engine presented power higher than or equal to that obtained with B25 mixtures, considering the same mixture. In addition, all diesel/biodiesel ratios containing biodiesel mixtures of soybean and castor bean, regardless of the concentration studied, present sufficient power performance, in the range of 2400 to $1500 \mathrm{rpm}$, taking as reference the diesel, since the power values are higher or equivalent to the B7, as observed in the $1500 \mathrm{rpm}$ rotation.

The binary mixtures with higher proportions of biodiesel can promote good performance of diesel engine, considering the increase in cetane number in mixtures containing higher levels of biodiesel, which improves the combustion of the fuel in the combustion chamber. In addition, studies show that the engine presents better thermal efficiency with the use of larger proportions of biodiesel, which contributes to increase the performance (Monteiro et al., 2013).

Among the mixtures tested, the ones that provided the best engine power performance, on average (Table 2), were the B40 proportions, containing 100\% soybean biodiesel (S100C0), followed by the S75C25 mixture, with an equivalent power achieved with the B7 (commercial diesel). The satisfactory result of B40 S100C0 and B40 $\mathrm{S} 75 \mathrm{C} 25$ is linked to the higher power developed by these fuels at below-peak rotations, with better performance under these conditions compared to the commercial diesel.

Regarding the specific engine consumption, the highest value occurred in the rotation of $1500 \mathrm{rpm}$, independent of the BX/SyCx mixture (Figure 2). 
A

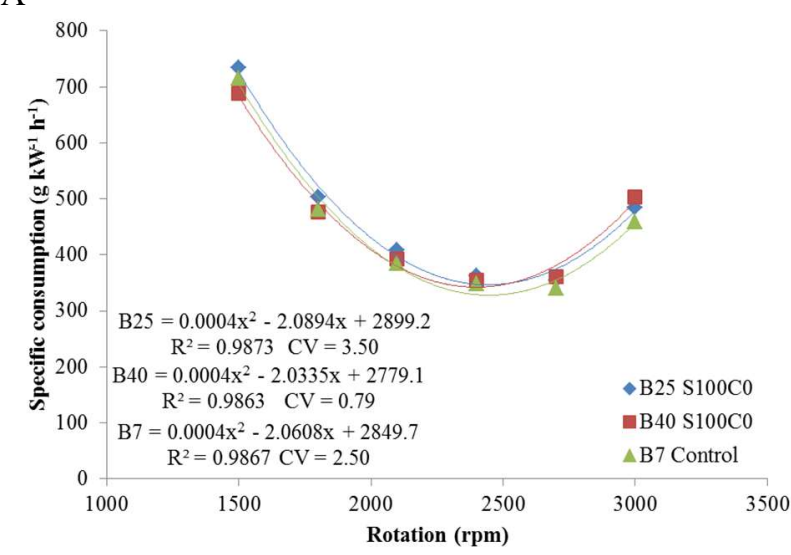

$\mathrm{C}$

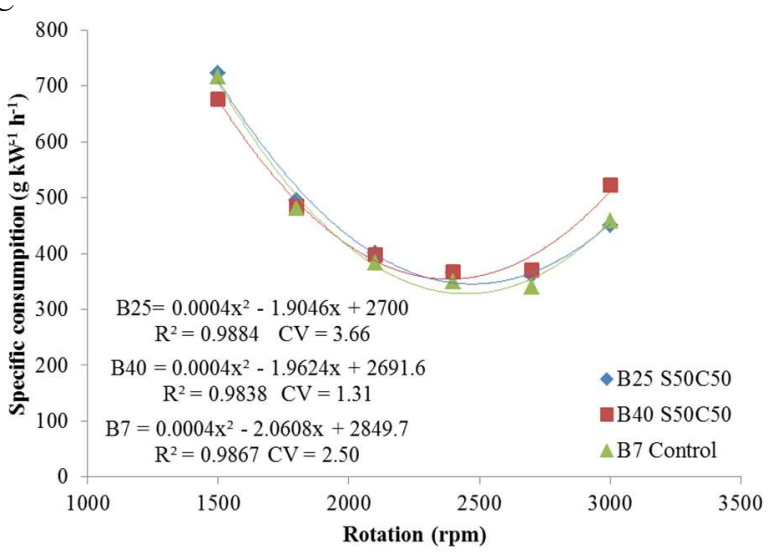

B

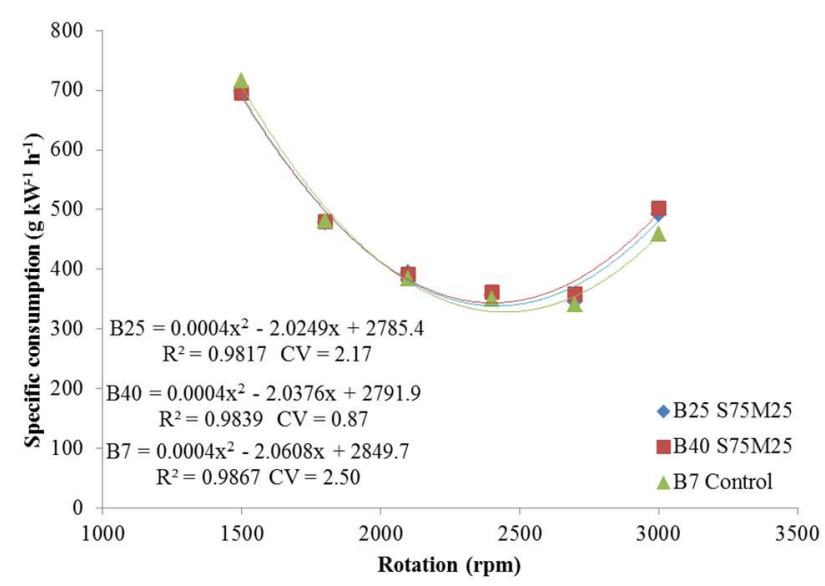

$\mathrm{D}$

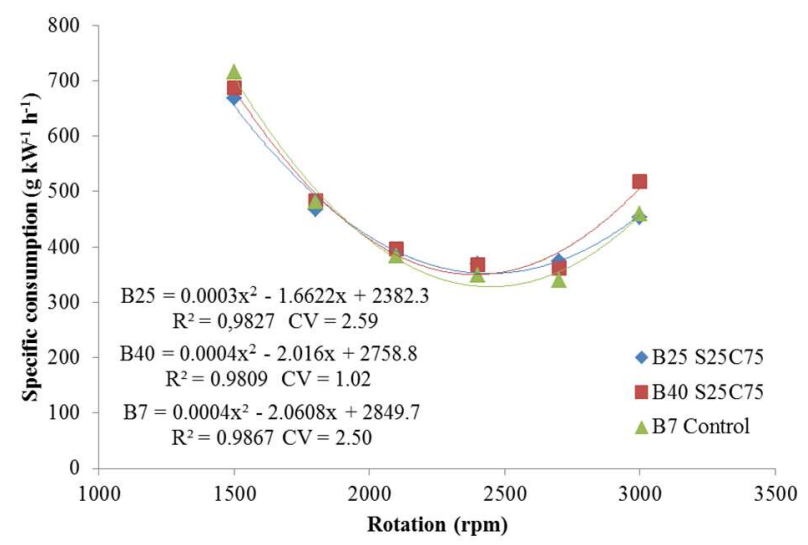

E

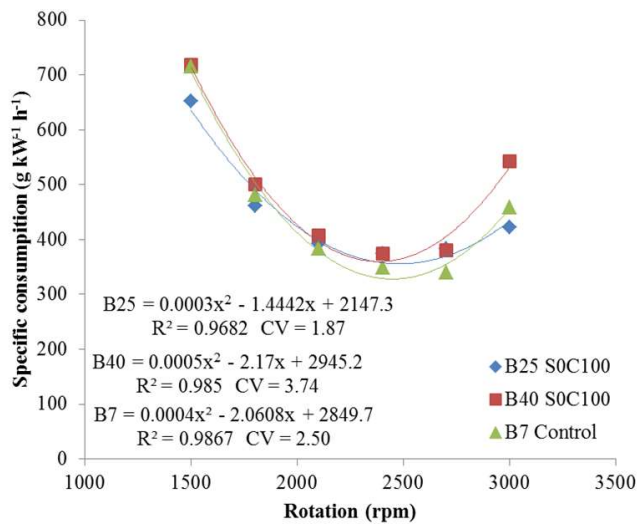

FIGURE 2. Curves of specific consumption according to the engine rotation, using the proportions $\mathrm{B} 25$ and $\mathrm{B} 40$ with the mixtures: (A) S100C0; (B) S75C25; (C) S50C50; (D) S25C75 and (E) S0C100 compared to the diesel B7 control.

The increase in engine speed reduces the specific consumption until it reaches its minimum value at speeds of 2400 and $2700 \mathrm{rpm}$ (Figure 2). From this point, the increased rotation promotes increase in specific consumption.

In the maximum rotation, where the engine develops higher power, there is an increase in the specific consumption for proportions with $40 \%$ biodiesel (B40), mainly for mixtures with higher concentration of castor bean biodiesel (S0C100) (Figure 2). On the other hand, the increase of biodiesel of castor bean in proportions with $25 \%$ of biodiesel (B25) reduces the specific consumption of the engine in the rotation of $3000 \mathrm{rpm}$, so that the lowest value found in this condition was with the use of B25 S0C100, in comparison also with commercial diesel.

The lowest specific consumption (Table 3) occurred with the use of B25 (S25C75, S0C100) and B40 (S100C0, $\mathrm{S} 50 \mathrm{C} 50$ and S0C100) for the rotation of $2400 \mathrm{rpm}$ and B7, $\mathrm{B} 25$ (S100C0, S75C25 and S50C50) and $\mathrm{B} 40$ (S75C25 and $\mathrm{S} 25 \mathrm{C} 75)$ for the rotation of $2700 \mathrm{rpm}$. In addition, the mixtures B25 S0C100 and B25 S25C75 presented lower consumption in the majority of the rotations, which contributed to a lower average consumption, equal to that obtained with commercial diesel (B7). 
TABLE 3. Average of the specific consumption for the BX/SyCx mixtures as a function of the rotation, the overall average of the specific consumption as a function of biodiesel types/proportions and variance analysis synthesis.

\begin{tabular}{|c|c|c|c|c|c|c|c|}
\hline \multicolumn{8}{|c|}{ Consumption $\left(\mathrm{g} \mathrm{kW}^{-1} \mathrm{~h}^{-1}\right)$} \\
\hline \multirow{2}{*}{\multicolumn{2}{|c|}{ BX/SyCx Mixtures }} & \multicolumn{3}{|c|}{ Rotation (rpm) } & \multirow[b]{2}{*}{1800} & \multirow[b]{2}{*}{1500} & \multirow{2}{*}{$\begin{array}{l}\text { Overall } \\
\text { average }\end{array}$} \\
\hline & & 2700 & 2400 & 2100 & & & \\
\hline B25 S100C0 & $485 \mathrm{c}$ & 354 cde & $363 \mathrm{ab}$ & $408 \mathrm{a}$ & $504 \mathrm{a}$ & $734 a$ & $475 \mathrm{~b}$ \\
\hline B40 S100C0 & $503 \mathrm{bc}$ & $361 \mathrm{bcd}$ & $355 \mathrm{ab}$ & $392 \mathrm{ab}$ & 476 cde & $689 \mathrm{de}$ & $467 \mathrm{~cd}$ \\
\hline B25 S75C25 & $491 \mathrm{c}$ & $345 \mathrm{de}$ & $356 \mathrm{ab}$ & $395 \mathrm{ab}$ & 478 cde & 698 bcd & $461 \mathrm{cde}$ \\
\hline B40 S75C25 & $502 \mathrm{bc}$ & 358 cde & $362 \mathrm{ab}$ & $391 \mathrm{ab}$ & 480 bcde & 695 cde & $464 \mathrm{c}$ \\
\hline B25 S50C50 & $451 \mathrm{~d}$ & 360 bcde & $365 \mathrm{ab}$ & $401 \mathrm{ab}$ & $495 \mathrm{abc}$ & $722 \mathrm{a}$ & $466 \mathrm{c}$ \\
\hline B40 S50C50 & $522 \mathrm{ab}$ & 370 abcd & $367 \mathrm{ab}$ & $398 \mathrm{ab}$ & 484 abcd & $676 \mathrm{ef}$ & $470 \mathrm{bc}$ \\
\hline B25 S25C75 & $453 \mathrm{~d}$ & $374 \mathrm{abc}$ & $369 \mathrm{ab}$ & $392 \mathrm{ab}$ & $468 \mathrm{de}$ & $668 \mathrm{fg}$ & 454 ef \\
\hline B40 S25C75 & $518 \mathrm{~b}$ & $362 \mathrm{abcd}$ & $367 \mathrm{ab}$ & $396 \mathrm{ab}$ & 484 abcd & $687 \mathrm{def}$ & $469 \mathrm{bc}$ \\
\hline B25 S0C100 & $422 \mathrm{e}$ & $383 \mathrm{a}$ & $374 \mathrm{a}$ & $392 \mathrm{ab}$ & $462 \mathrm{e}$ & $653 \mathrm{~g}$ & $448 \mathrm{f}$ \\
\hline B40 S0C100 & $543 \mathrm{a}$ & $380 \mathrm{ab}$ & $375 a$ & $407 \mathrm{a}$ & $501 \mathrm{ab}$ & $718 \mathrm{ab}$ & $487 \mathrm{a}$ \\
\hline B7 & $459 \mathrm{~d}$ & $340 \mathrm{e}$ & $349 \mathrm{~b}$ & $384 \mathrm{~b}$ & $481 \mathrm{bcde}$ & $716 \mathrm{abc}$ & $455 \mathrm{def}$ \\
\hline \multicolumn{4}{|c|}{$\mathrm{CV} \%$} & \multicolumn{4}{|c|}{2.45} \\
\hline
\end{tabular}

Averages followed by same letter in column do not differ by Tukey test $(\mathrm{p}<0.05)$. CV: coefficient of variation $(\%)$.

The torque reached the highest values at $3000 \mathrm{rpm}$ (Figure 3). In this rotation, the commercial diesel (B7) and the proportion $\mathrm{B} 25$, containing $\mathrm{S} 100 \mathrm{C} 0$, presented higher torque, being verified reduction with the increase of castor bean biodiesel in the mixtures. According to Monteiro et

A

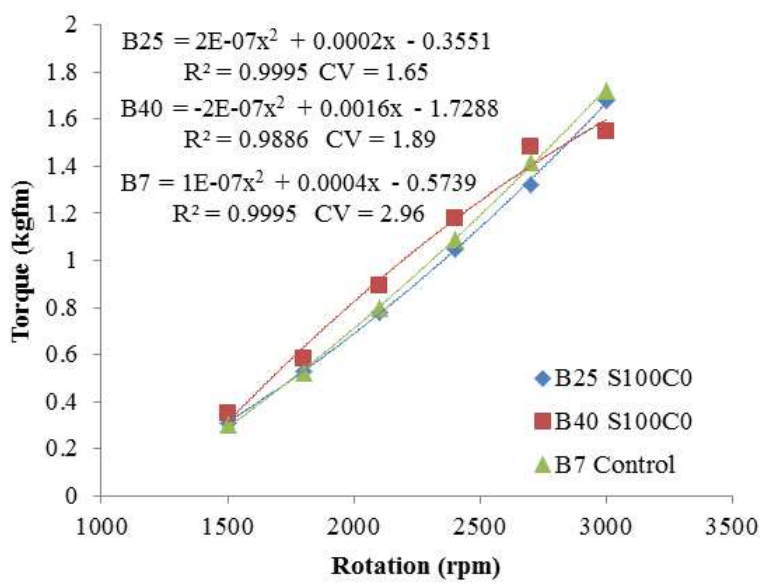

$\mathrm{C}$

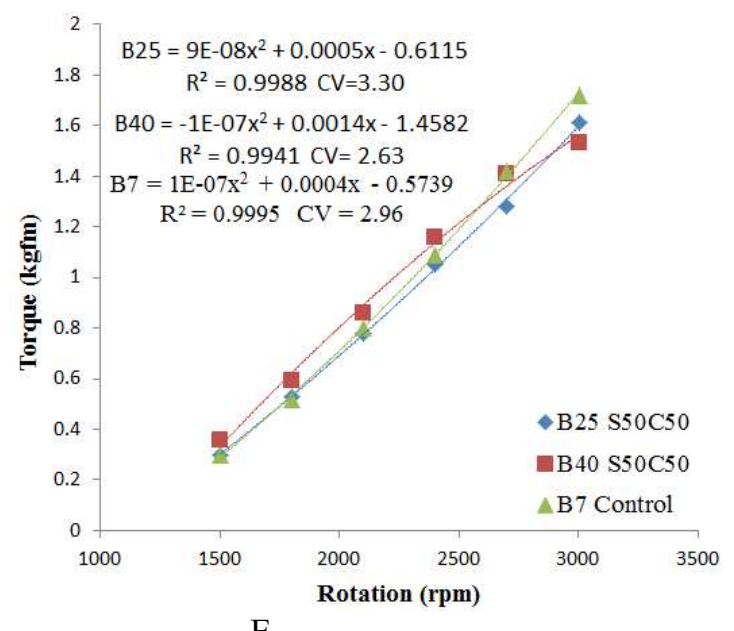

al. (2013), the density and the high compressibility of the fuel from the castor bean can compromise the operation of the injection system and thus reduce the torque compared to that developed with diesel and other $\mathrm{Bx} / \mathrm{SyCx}$ mixtures at $3000 \mathrm{rpm}$.

B

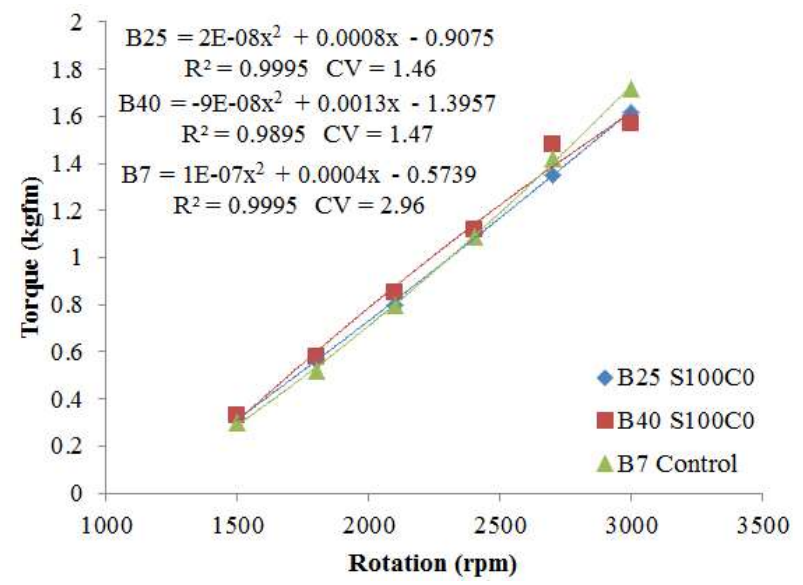

$\mathrm{D}$

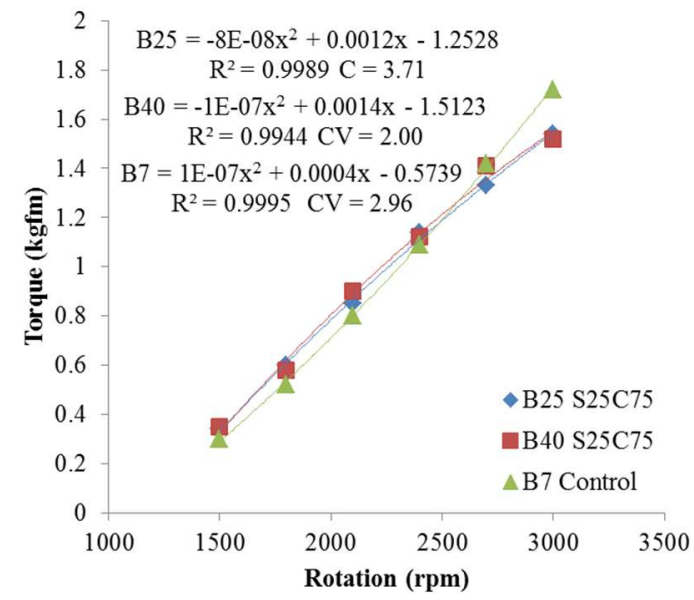




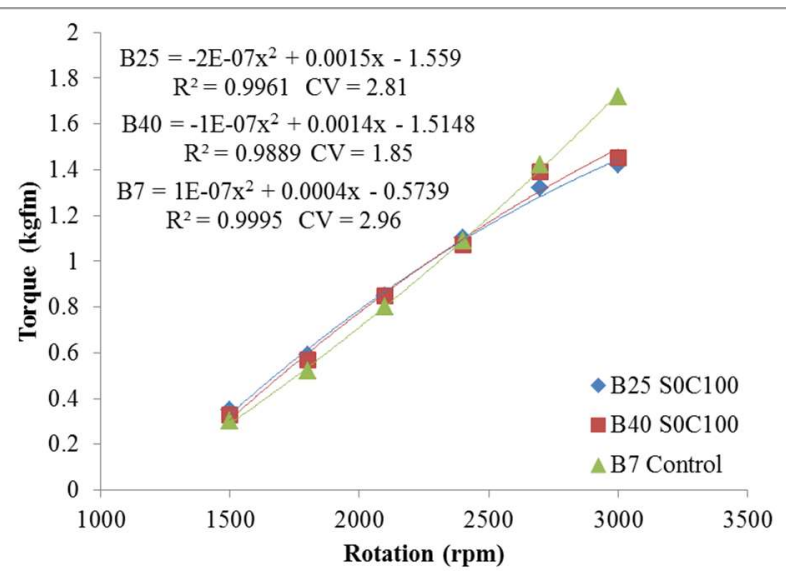

FIGURE 3. Curves of torque as a function of engine speed, using proportions B25 and B40 with mixtures: (A) S100C0; (B) S75C25; (C) S50C50; (D) S25C75 and (E) S0C100 compared to the diesel B7 control.

Compared to the fossil diesel, the biodiesel presents higher values in the number of cetane (Lôbo et al., 2009), being higher for soybean than for castor bean. Thus, the thermal efficiency and cetane number compensated for the lower calorific value and higher viscosity of the B25 $\mathrm{S} 100 \mathrm{C} 0$ in relation to the diesel, maintaining the torque similar to that of $\mathrm{B} 7$ at maximum rotation.

At the other rotations, for the SyCx mixtures under analysis, the B40 tends to have a torque result greater than or equal to that developed with B25 of the same mixture, generally resulting in better performance of B40 (Figure 3).

In general, the highest torque was obtained with the use of B40 S100C0 and B40 S75C25 (Table 4), whose result is $3 \%$ higher than that developed by the engine with the use of commercial diesel (B7). This is because the mixtures cited have better performances than the B7 at speeds below $3000 \mathrm{rpm}$, which influences the overall result.

TABLE 4. Average of the torque for the $\mathrm{BX} / \mathrm{SyCx}$ mixtures as a function of the rotation, the overall average of the torque as a function of biodiesel types/proportions and variance analysis synthesis.

\begin{tabular}{|c|c|c|c|c|c|c|c|}
\hline \multicolumn{8}{|c|}{ Torque (kgf.m) } \\
\hline \multirow{2}{*}{\multicolumn{2}{|c|}{ BX/SyCx Mixtures $\overline{3000}$}} & \multicolumn{3}{|c|}{ Rotation (rpm) } & \multirow[b]{2}{*}{1800} & \multirow[b]{2}{*}{1500} & \multirow{2}{*}{$\begin{array}{l}\text { Overall } \\
\text { average }\end{array}$} \\
\hline & & 2700 & 2400 & 2100 & & & \\
\hline $\mathrm{B} 25 \mathrm{~S} 100 \mathrm{C} 0$ & $1.68 \mathrm{a}$ & $1.32 \mathrm{de}$ & $1.05 \mathrm{f}$ & $0.78 \mathrm{~d}$ & $0.53 \mathrm{bc}$ & $0.31 \mathrm{bcd}$ & $0.94 \mathrm{efg}$ \\
\hline B40 S100C0 & $1.55 \mathrm{~cd}$ & $1.48 \mathrm{a}$ & $1.18 \mathrm{a}$ & $0.89 \mathrm{ab}$ & $0.58 \mathrm{a}$ & $0.35 \mathrm{ab}$ & $1.00 \mathrm{a}$ \\
\hline $\mathrm{B} 25 \mathrm{~S} 75 \mathrm{C} 25$ & $1.62 \mathrm{~b}$ & $1.35 \mathrm{~cd}$ & 1.10 cde & $0.80 \mathrm{~cd}$ & $0.56 \mathrm{abc}$ & $0.32 \mathrm{abcd}$ & $0.96 \mathrm{de}$ \\
\hline B40 S75C25 & $1.57 \mathrm{c}$ & $1.48 \mathrm{a}$ & $1.12 \mathrm{bcd}$ & $0.85 \mathrm{ab}$ & $0.58 \mathrm{a}$ & $0.33 \mathrm{abcd}$ & $0.99 \mathrm{ab}$ \\
\hline B25 S50C50 & $1.61 \mathrm{~b}$ & $1.28 \mathrm{e}$ & $1.05 \mathrm{f}$ & $0.78 \mathrm{~d}$ & $0.53 \mathrm{bc}$ & $0.30 \mathrm{~d}$ & $0.93 \mathrm{~g}$ \\
\hline B40 S50C50 & $1.53 \mathrm{~cd}$ & $1.41 \mathrm{~b}$ & $1.16 \mathrm{ab}$ & $0.86 \mathrm{ab}$ & $0.59 \mathrm{a}$ & $0.36 \mathrm{a}$ & $0.98 \mathrm{~b}$ \\
\hline B25 S25C75 & $1.54 \mathrm{~cd}$ & $1.33 \mathrm{~d}$ & $1.14 \mathrm{abc}$ & $0.85 \mathrm{bc}$ & $0.60 \mathrm{a}$ & $0.34 \mathrm{abc}$ & $0.97 \mathrm{~cd}$ \\
\hline B40 S25C75 & $1.52 \mathrm{~d}$ & $1.41 \mathrm{~b}$ & $1.12 \mathrm{bcd}$ & $0.90 \mathrm{a}$ & $0.58 \mathrm{a}$ & $0.35 \mathrm{ab}$ & $0.98 \mathrm{bc}$ \\
\hline B25 S0C100 & $1.42 \mathrm{e}$ & $1.32 \mathrm{de}$ & $1.10 \mathrm{cde}$ & $0.85 \mathrm{ab}$ & $0.59 \mathrm{a}$ & $0.35 \mathrm{ab}$ & $0.94 \mathrm{fg}$ \\
\hline B40 S0C100 & $1.45 \mathrm{e}$ & $1.39 \mathrm{bc}$ & $1.07 \mathrm{ef}$ & $0.85 \mathrm{bc}$ & $0.57 \mathrm{ab}$ & $0.33 \mathrm{abcd}$ & $0.95 \mathrm{ef}$ \\
\hline B7 & $1.72 \mathrm{a}$ & $1.42 \mathrm{~b}$ & $1.09 \mathrm{def}$ & $0.80 \mathrm{~d}$ & $0.52 \mathrm{c}$ & $0.30 \mathrm{~cd}$ & $0.97 \mathrm{bcd}$ \\
\hline \multicolumn{4}{|c|}{$\mathrm{CV} \%$} & \multicolumn{4}{|c|}{2.44} \\
\hline
\end{tabular}

Averages followed by same letter in column do not differ by Tukey test $(\mathrm{p}<0.05)$. CV: coefficient of variation $(\%)$.

Factor that also justifies the effects of improvement in the efficiency of the engine operating with greater proportions of biodiesel, comes from the reduction of the friction of the moving and static parts of the engine, due to the lubrication action that the biodiesel holds, when compared with diesel oil (Fiorese et al., 2012).

Studies with biodiesel from castor bean using mixtures containing 10 and $20 \%$ of biodiesel in mixture with diesel, indicate viability, both for electric generation and for mobility (Monteiro et al., 2013), because with the use of these fuels the engines had similar or superior performance to that obtained with diesel. The concentrations of castor bean biodiesel in the mixture are higher than those studied by other authors, but the B25 and $\mathrm{B} 40$ mixtures of castor bean (S0C100) presented similar results of similar power and torque, however lower than that obtained with diesel (B7).

It was possible to identify that the performance of the engine in the rotation of $2700 \mathrm{rpm}$ is improved with the use of mixtures B40 S100C0 and B40 S75C25, since it obtained greater effective power observed and torque, comparing with the other fuels tested, besides the specific consumption is feasible, making these mixtures more suitable for the operation of the engine in this operating regime. In addition, they stand out when considering the average result, providing average power, equivalent to the diesel, and higher average torque, compared to diesel, which makes them appropriate when considering the average total performance. 
The agricultural operations in diesel-powered tractors are usually conducted at lower rotations in a working range between 1200 and $2100 \mathrm{rpm}$ (Fiorese et al., 2012), being below the maximum rotation evaluated in this study (3000 rpm), which reinforces the results obtained in the minor rotations, favoring the use of the mixtures used. In this sense, Silveira et al. (2013) verified that when using a no-tillage tractor set in no-tillage system in the range of 1500 to $2100 \mathrm{rpm}$, which the rotation of $1500 \mathrm{rpm}$ provides a reduction of hourly consumption in relation to the maximum rotation, since it is influenced by rotation and speed used in agricultural operations.

Thus, considering the rotation range of agricultural tractors, the condition of operation (rotation) highlighted by Silveira et al. (2013) and the results found in this study, it was possible to identify that the proportions with up to $40 \%$ of diesel containing mixtures of soybean and castor bean biodiesel present promising use.

\section{CONCLUSIONS}

The mixtures of biodiesel from soybean and castor bean added to diesel in the proportions of 25 and $40 \%$ are feasible for use in a stationary diesel cycle engine, which performance curves are similar to those developed with commercial diesel (B7).

Although the highest consumption in the rotation of $1500 \mathrm{rpm}$ for all fuels (mixtures) under analysis, with similar and decreasing behavior until reaching a minimum value and then increasing behaviors from $3000 \mathrm{rpm}$, the analysis of the consumption correlation with the composition of the mixtures and operating conditions (rotations) allowed to identify different minimum consumptions for the mixtures in rotations in that interval. For the rotations of 2400 and $2700 \mathrm{rpm}$, for example, the lowest consumption for the B40 S100C0 and the B40 $\mathrm{S} 75 \mathrm{C} 25$, respectively, is verified. In addition, the mixtures B25 S0C100 and B25 S25C75 presented lower consumption in the majority of the rotations, which contributed to a lower average consumption, equal to that obtained with commercial diesel (B7).

The operating regime influences the results, so mixtures of biodiesel of soybean and castor bean in the proportions of 25 and $40 \%$ in mixture with the diesel promote better or similar performance of the engine, in relation to the $\mathrm{B} 7$, in the rotations below $2700 \mathrm{rpm}$. In the rotation of $3000 \mathrm{rpm}$, the best performance of power, consumption and torque is ensured by diesel.

On average, the B40 S100C0 and the B40 S75C25 provide satisfactory engine performance over diesel.

\section{ACKNOWLEDGEMENTS}

We would like to thank the FAPESB - Fundação de Amparo à Pesquisa from the State of Bahia, by granting the second author a master's scholarship. Also to UFGD for the financial support for execution and dissemination of this study.

\section{REFERENCES}

ANP - Agência Nacional de Petróleo, Gás Natural e Biocombustíveis (2014) RANP 45. Available in: http://legislacao.anp.gov.br/?path=legislacao-anp/resolanp/2014/agosto\&item=ranp-45--2014. Accessed: Aug 13, 2018 .
Ballesteros R, Guillén-Flores J, Martínez JD (2014)

Carbonyl emission and toxicity profile of diesel blends with an animal-fat biodiesel and a tire pyrolysis liquid fuel. Chemosphere 96:155-166.

Boldaji MT, Ebrahimzadeh R, Kheiralipour K, Borghei AM (2011) Effect of some BED blends on the equivalence ratio, exhaust oxygen fraction and water and oil temperature of a diesel engine. Biomass and Bioenergy 35:4099-4106.

Carvalho AL, Santana SMF, Silva SC, Pepe IM, Bezerra MA, Aragão LM, Quintella CM, Teixeira LSG (2013) Evaluation of the Oxidative Stability of Biodiesel Blends from Soybean, Tallow and Castor Bean using Experimental Mixture Design. Journal of the Brazilian Chemical Society 24(8):1373-1379.

Castellanelli M, Souza SNM, Silva SL, Kaier EK (2008)

Desempenho de motor ciclo diesel em bancada dinamométrica utilizando misturas diesel/ biodiesel. Revista Engenharia Agrícola 28(1):145-153.

Chauhan BS, Kumar N, Cho HM, Lim HC (2013) A study on the performance and emission of a diesel engine fueled with Karanja biodiesel and its blends. Energy 56:1-7.

Fiorese DA, Dallmeyer AU, Romano LN, Schlosser JF, Machado PRM (2012) Desempenho de um motor de trator agrícola em bancada dinamométrica com biodiesel de óleo de frango e misturas binárias com óleo diesel. Ciência Rural 42(4):660-666.

Iscan B, Aydin H (2012) Improving the usability of vegetable oil as fuel in a low heat rejection diesel engine. Fuel Processing Technology 98:59-64.

Kosow IL (1982) Máquinas elétricas e transformadores. Rio de Janeiro, Globo.

Lôbo IP, Ferreira SLC, Cruz RS (2009) Biodiesel: parâmetros de qualidade e métodos analíticos. Química Nova 32(6):1596-1608.

Nietiedt GH, Schlosser JF, Ribas RL, Frantz UG, Russini A (2011) Desempenho de motor de injeção direta sob misturas de biodiesel metílico de soja. Ciência Rural 41(7):1177-1182.

Mialhe LG (1980) Máquinas motoras na agricultura. São Paulo, EDUSP, v.1. 367p.

Mialhe LG (1996) Máquinas agrícolas: ensaios \& certificação. Piracicaba, FEALQ. 722p.

Monteiro LA, Pianovski Júnior G, Velásquez JA, Rocha DS, Bueno AV (2013) Performance impact of the application of castor oil biodiesel in diesel engines. Engenharia Agrícola 33(6):1165-1171.

Perin GF, Schlosser JF, Farias MS, Estrada JS, Treichel H, Galon L (2015) Emissões de motor agrícola com o uso de diferentes tipos de diesel e concentrações de biodiesel na mistura combustível. Pesquisa Agropecuária Brasileira 50(12):1168-1176.

Rashid N, Rehman MSU, Sadiq M, Mahmood T, Han JI (2014) Current status, issues and developments in microalgae derived biodiesel production. Renewable and Sustainable Energy Reviews 40:760-778. 
Reis EF, Cunha JPB, Mateus DLS, Delmond JG, Couto RF (2013) Desempenho e emissões de um motor-gerador ciclo diesel sob diferentes concentrações de biodiesel de soja. Revista Brasileira de Engenharia Agrícola e Ambiental 17(5):565-571.

Selvam DJP, Vadivel K (2013) An experimental investigation on performance, emission, and combustion characteristics of a diesel engine fueled with methyl esters of waste pork lard and diesel blends. International Journal of Green Energy 10:908-923.
Silveira JCM, Fernandes HC, Modolo AJ, Silva SL, Trogello E (2013) Demanda energética de uma semeadoraadubadora em diferentes velocidades de deslocamento e rotações do motor. Revista Ciência Agronômica 44(1):4452.

Zhou W, Chen P, Min M, Ma X, Wang J, Griffith R, Hussain F, Peng P, Xie Q, Li Y, Shi J, Meng J, Ruan R (2014) Renvironment-enhancing algal biofuel production using wastewater. Renewable and Sustainable Energy Reviews 36:256-269. 